\title{
Sensitifitas dan Spesifisitas Pemeriksaan Procalcitonin, C-Reactive Protein [CRP], dan Hitung Leukosit untuk Memprediksi Infeksi Bakterial pada Sindrom Syok Dengue di Pediatric Intensive Gare Unit
}

\author{
Henny Rosita Iskandar, * Antonius Pudjiadi, ** Dharma Mulyo, * A. Pratiwi, *Y. Suryatin * \\ *RSAB Harapan Kita, Jakarta. \\ **Departemen Ilmu Kesehatan Anak, FK Universitas Indonesia, RSUPN Dr. Cipto Mangunkusumo, Jakarta.
}

\begin{abstract}
Latar belakang. Pada sindrom syok dengue (SSD) dapat terjadi iskemia usus yang dapat menyebabkan gangguan gut barrier sehingga terjadi translokasi bakteri dan produknya (endotoksin) ke dalam sirkulasi sistemik. Di Indonesia, terdapat beberapa pemeriksaan laboratorium yang tersedia untuk mendeteksi infeksi bakteri antara lain procalcitonin (PCT), CRP, hitung leukosit, dan biakan bakteri, sedangkan pemeriksaan neoptrin dan endotoksin belum tersedia secara komersial. Biakan darah memerlukan waktu yang lama dan dapat memperburuk prognosis bila pemberian antibiotik harus menunggu hasil pemeriksaan.

Tujuan. Mengetahui sensitivitas dan spesifisitas pemeriksaan PCT, CRP, dan hitung leukosit untuk memprediksi infeksi bakteri pada pasien SSD yang dirawat di pediatic intensive care unit (PICU).

Metode. Studi prospektif kasus SSD yang dirawat di PICU RSAB Harapan Kita Jakarta dari Januari sampai dengan Desember 2006. Diagnosis SSD sesuai dengan kriteria WHO 1997 dikonfirmasi dengan pemeriksaan serologi Dengue blot pada hari kelima demam. Pemeriksaan PCT, CRP, biakan darah, dan hitung leukosit pada hari pertama masuk PICU. Data dianalisis dengan program SPSS versi 17.

Hasil. Subyek penelitian didapatkan 28 pasien dengan umur 12 bulan sampai 180 bulan (rerata 86 bulan, SD 39 bulan). Seluruh kasus merupakan infeksi dengue sekunder. Kematian terjadi pada 3 dari 28 pasien $(10,7 \%$ ). PCT (cut of point $>0,5 \mathrm{ng} / \mathrm{ml}$ ), CRP (cut of point $>6 \mathrm{mg} / \mathrm{l}$ ) dan hitung leukosit (cut of point $>11.000 /$ IU) tidak berkorelasi secara bermakna dengan hasil biakan. Receiver operating characteristic curves (ROC) PCT 0.400 dengan $\mathrm{p}=0.490$ dan CRP 0,422 dengan $\mathrm{p}=0,549$, hitung leukosit 0,500 dengan $\mathrm{p}=1,000$. Perbandingan sensitifitas dan spesifisitas PCT ,CRP, dan hitung leukosit masing-masng $20 \%$ dan $30,4 \%$ CRP $60 \%$ dan $69,6 \%$ sedangkan leukosit $20 \%$ dan $21,7 \%$

Kesimpulan. Pemeriksaan PCT, CRP, dan hitung leukosit tidak dapat digunakan untuk memprediksi infeksi bakterial pada pasien SSD di PICU. Sari Pediatri 2010;12(4):233-40.
\end{abstract}

Kata kunci: PCT, CRP, infeksi bakterial, SSD, PICU.

\section{Alamat korespondensi:}

Dr. Henny Rosita Iskandar, Sp.A. Pediatic Intensive Care Unit. Kompleks perumahan dokter RSAB Harapan Kita blok A no 4 Jl S.Parman kav 87 Slipi Jakarta Barat. 


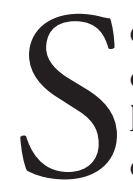
ecara tradisional, infeksi berat dapat dikenali dari beberapa tanda klinis seperti hiper atau hipotermia, takikardi, takipnu, hipotensi ditambah beberapa data laboratorium rutin seperti hitung leukosit, kadar $C$-reactive protein. Namun demikian, tidak jarang ditemukan hasil laboratorium rutin dalam rentang normal. Parameter lain yang digunakan antara lain adalah sitokin proinflamasi, seperti TNF- $\alpha$, IL- $1 \beta$ dan IL-6. Sayangnya, kadar sitokin proinflamasi biasanya hanya meningkat untuk waktu yang relatif singkat.

Indonesia dikategorikan oleh WHO sebagai negara dengan status ' $A$ ', yaitu negara dengan demam dengue (DD) atau demam berdarah dengue (DBD) sebagai masalah kesehatan publik, menyebabkan banyak kasus yang perlu dirawat di rumah sakit, dapat menyebabkan kematian, dijumpai siklus epidemik mulai dari perkotaan yang menyebar ke pedesaan, dan berbagai serotipe yang beredar. Sejak tahun 2007, DBD di Indonesia merupakan negara dengan jumlah kasus terbesar di dunia, lebih dari 155.000/tahun. Case fatality rate (CFR) DBD di Indonesia cukup tinggi sampai 4,6\% pada tahun 1987, 2-3\% pada 1991-1999, dan kurang dari $2 \%$ sejak tahun 2000. Angka kematian nasional DBD terendah 0,60\% terjadi pada tahun 2008. Berdasarkan data dari WHO, CFR DBD pada beberapa negara pada tahun 2009 adalah: Indonesia 0,89\%. Thailand 0,01 $\%$, India 0,62\%, dan Sri Lanka 0,99\%. ${ }^{1}$ Di Indonesia angka kematian SSD menurun dari $26 \%$ pada tahun 1996 menjadi $12 \%$ pada tahun $2002 .^{2}$

Procalcitonin adalah polipeptida yang terdiri dari 116 asam amino dan merupakan prohormon calcitonin. Calcitonin terdiri dari 32 asam amino, sedangkan PCT dibentuk oleh prePCT yang terdiri dari 141 asam amino dengan bobot molekul $16 \mathrm{kDa}$. Pemecahan terjadi di sel C kelenjar tiroid. ${ }^{3,4}$ Pemeriksaan semikuantitatif PCT sangat praktis dan dapat digunakan secara bed-side. Peningkatan PCT yang cukup besar terjadi bila terdapat reaksi peradangan sistemik yang disebabkan oleh endotoxin bakteri, exotoxin, dan beberapa jenis sitokin. ${ }^{5}$ Beberapa penyakit di luar infeksi yang dapat meningkatkan PCT antara lain malaria penyakit jamur, ${ }^{6,7}$ penyakit autoimun, ${ }^{5}$ bedah jantung, ${ }^{8}$ pankreatitis, ${ }^{9}$ luka bakar, ${ }^{10}$ penyakit Kawasaki, ${ }^{11}$ dan syok kardiogenik. ${ }^{12}$ Terjadi peningkatan sedikit kadar PCT pada keadaan infeksi virus, neoplastik, dan penyakit autoimun, sedangkan pada infeksi bakteri kronik tanpa inflamasi, reaksi alergi, dan infeksi bak- terial yang terlokalisasi tidak didapatkan peningkatan PCT. ${ }^{13}$ Konsentrasi normal PCT dalam serum/plasma di bawah $0,5 \mathrm{ng} / \mathrm{ml}$. Pada keadaan inflamasi kronik dan penyakit autoimun, infeksi virus, dan infeksi lokal kadar PCT $<0,5 \mathrm{ng} / \mathrm{ml}$, sedangkan pada keadaan SIRS, multipel trauma, dan luka bakar kadar PCT 0,5-2 ng/ $\mathrm{ml}$ dan kadar PCT >2 (paling sering 10-100) $\mathrm{ng} / \mathrm{ml}$ merupakan prediktor infeksi berat, sepsis, dan kegagalan beberapa organ (multiple organ failure). ${ }^{14}$

$C$-reactive protein (CRP) merupakan protein pentamer siklik $115 \mathrm{kDa}$ yang terdiri dari 5 protomer. Masing-masing protomer terdiri dari 206 asam amino. Dinamakan C-reaktif protein karena mempunyai kemampuan untuk mengikat somatic $C$ polisakarida dari Streptococcus pneumonia. Beberapa penelitian mengatakan bahwa pemeriksaan CRP $>30 \mathrm{mg} / \mathrm{l}$ didapati sensitifitas $81 \%$, spesifisitas $89 \%$, PPV $91 \%$, dan NPV $76 \%,{ }^{15}$ namun peneliti lain mengatakan kadar CRP tidak berbeda bermakna antara sepsis dan SIRS. ${ }^{16}$

Beberapa pemeriksaan laboratorium klinis untuk mendeteksi adanya infeksi dalam darah di antaranya pemeriksaan endotoksin, PCT, CRP, leukosit, IT ratio, dan neoptrin. Pemeriksaan yang tersedia secara komersial di Jakarta hanya berupa pemeriksaan CRP, IT ratio dan leukosit, sedangkan PCT, neoptrin dan endotoksin belum tersedia secara komersial. Untuk penelitian kami, dipergunakan pemeriksaan semikuantitatif PCT dari produsernya B.R.A.H.M.S Diagnostica AG, Hennigsdorf/Berlin, Germany lewat agennya di Indonesia.

\section{Metode}

Penelitan prospektif dengan melibatkan 28 pasien anak, 50\% perempuan, dirawat di PICU RSAB Harapan Kita dari Januari sampai dengan Desember 2006. Diagnosis DSS ditegakkan berdasarkan kriteria WHO tahun 1997 dan diagnosis konfirmasi dilakukan dengan pemeriksaan serologi IgG+IgM Dengue Blot yang dilakukan pada hari demam ke-5. Skor PELOD dan PRISM III dihitung pada hari pertama masuk PICU. Data yang didapat seperti umur, jenis kelamin, asal pasien, keluaran, dan lama dirawat di PICU sampai keluar atau meninggal dianalisis secara statistik dengan SPSS versi 17 . Perbandingan data dilakukan dengan chi-square test, nilai p kurang dari 0,05 dianggap bermakna secara statistik.

Penelitian telah disetujui oleh Komite Etik RSAB 
Henny Rosita Iskandar dkk: Sensitifitas dan spesifisitas pemeriksaan PCT, CRP, dan hitung leukosit untuk memprediksi infeksi pada pasien PICU dengan SSD

Harapan Jakarta. Informed consent didapatkan dari orang tua subyek penelitian. Pemeriksaan PCT, CRP, hitung leukosit dan biakan darah dilakukan pada hari pertama masuk PICU.

\section{Hasil}

Terdapat 75 orang pasien SSD selama bulan Januari sampai Desember 2006 yang dirawat di PICU RSAB Harapan Kita, namun hanya 40 pasien yang bersedia ikut dalam penelitian. Dari 40 pasien 28 di antaranya diikutkan dalam penelitian, sedangkan darah dari 12 pasien lainnya lisis sehingga hasil tidak dapat dinilai.

Tabel 1 memperlihatkan karakteristik subyek penelitian dengan rentang umur dari 12 sampai dengan 180 bulan, rerata umur 86 bulan dan SB 39 bulan. Kelompok usia 5-9 tahun adalah kelompok umur yang terbanyak yaitu 17 dari 28 subyek $(65,4 \%)$ dan menyusul kelompok usia $>10$ tahun 7 subyek $(31,8 \%)$. Jenis kelamin antara perempuan dan laki-laki tidak ada perbedaan masing-masing 50\%. Sebagian besar $(78,6 \%)$ termasuk gizi baik atau lebih. Semua subyek merupakan infeksi sekunder dengue (100\%) pada pemeriksaan Ig $\mathrm{G}$ dan Ig $\mathrm{M}$ didapatkan positif. Berdasarkan rujukan, 23 orang $(82,2 \%)$ dikirim melalui UGD dan hanya 5 orang $(17,8 \%)$ dikirim dari ruangan. Kematian terjadi pada 3 dari 28 orang $(10,7 \%)$. Gejala klinis menunjukkan perdarahan terjadi pada 12 pasien DSS dan gejala kejang (ensefalopati) pada 5 pasien, sedangkan hepatomegali dijumpai pada 6 pasien dan muntah pada 20 pasien

Tabel 1 menunjukkan kadar PCT normal pada hampir sebagian besar subyek penelitian $(57,1 \%)$, peningkatan ringan $14,3 \%$, peningkatan sedang pada $17,9 \%$ dan hanya $10,7 \%$ yang menunjukan adanya infeksi berat. Kadar CRP positif pada $25 \%$ subyek sedangkan leukositosis terjadi pada 50\% subyek, hemokonsentrasi ditemukan pada $46,4 \%$ pasien.

Tabel 4 menunjukkan rerata kadar PCT 0,93 $\mathrm{mg} / \mathrm{L}$, nilai ROC 0,400 mempunyai sensitifitas $20 \%$ dan spesifisitas 30,4\% dengan nilai $\mathrm{p}=0,490$. Rerata kadar CRP 8,4 mg/L nilai ROC 0,422 mempunyai sensitifitas $60 \%$ dan spesifisitas $69,6 \%$ dengan nilai $\mathrm{p}=0,589$. Sedangkan rerata kadar leukosit $8835 / \mathrm{iu}$ nilai ROC 0,500 mempunyai sensitifitas $20 \%$ dan spesifisitas $21,7 \%$ dengan $\mathrm{p}=1,00$

Tabel 4 menunjukkan pada PCT normal $<0,5$ terdapat 6 subyek, sedangkan nilai PCT $>10$ hanya
Tabel. 1. Karakteristik subyek penelitian dan hasil laboratorium

\begin{tabular}{|c|c|}
\hline Karakteristik & $\mathrm{n}(\%)$ \\
\hline Jumlah subyek & 28 \\
\hline \multicolumn{2}{|l|}{ Jenis kelamin, $\mathrm{n}(\%)$} \\
\hline Perempuan & $14(50)$ \\
\hline Laki-laki & $14(50)$ \\
\hline \multicolumn{2}{|l|}{ Umur, bulan } \\
\hline Rentang & $12-180$ \\
\hline Rerata & 86 \\
\hline SB & 39 \\
\hline \multicolumn{2}{|l|}{ Kelompok umur, tahun, n (\%) } \\
\hline \multicolumn{2}{|l|}{$<1$} \\
\hline$>1-5$ & $4(30,8)$ \\
\hline$>5-10$ & $17(65,4)$ \\
\hline$>10$ & $7(31,8)$ \\
\hline Lama rawat, hari, rerata, n (\%) & 4.07 \\
\hline \multicolumn{2}{|l|}{ Tipe infeksi dengue, $\mathrm{n}(\%)$} \\
\hline Sekunder & $28(100)$ \\
\hline \multicolumn{2}{|l|}{ Prognosis, n (\%) } \\
\hline Hidup & $25(89,3)$ \\
\hline Meninggal & $3(10,7)$ \\
\hline \multicolumn{2}{|l|}{ Rujukan, n (\%) } \\
\hline UGD & $23(82,2)$ \\
\hline Ruangan & $5(17,8)$ \\
\hline \multicolumn{2}{|l|}{ Status, gizi, n (\%) } \\
\hline Buruk & $4(14,3)$ \\
\hline Kurang & $2(7,1)$ \\
\hline Baik & $10(35,7)$ \\
\hline Lebih & $12(42,9)$ \\
\hline \multicolumn{2}{|l|}{ Demam, hari, n (\%) } \\
\hline 3 & $3(10,7)$ \\
\hline 4 & $7 \quad(25,0)$ \\
\hline 5 & $15(53,6)$ \\
\hline 6 & $0 \quad(0)$ \\
\hline 7 & $3(10,7)$ \\
\hline \multicolumn{2}{|l|}{ PCT, ng/L, n (\%) } \\
\hline$<0,5$ & $16(57,1)$ \\
\hline $0,5-2$ & $4(14,3)$ \\
\hline$>2-5$ & $5(17,9)$ \\
\hline$>10$ & $3(10,7)$ \\
\hline \multicolumn{2}{|l|}{ CRP, mg/L, n (\%) } \\
\hline Negatif & $21(75)$ \\
\hline Positif & $7(25)$ \\
\hline \multicolumn{2}{|l|}{ Leukositosis, n (\%) } \\
\hline Negatif & $14(50)$ \\
\hline Positif & $14(50)$ \\
\hline \multicolumn{2}{|l|}{ Hemokonsentrasi, n (\%) } \\
\hline Negatif & $14(50,0)$ \\
\hline Positif & $13(46,4)$ \\
\hline
\end{tabular}


Henny Rosita Iskandar dkk: Sensitifitas dan spesifisitas pemeriksaan PCT, CRP, dan hitung leukosit untuk memprediksi infeksi pada pasien PICU dengan SSD

Tabel 2. Rerata perbandingan PCT, leukosit, dan CRP

\begin{tabular}{ccccccc}
\hline Parameter & Mean & Cut of point & ROC & Sensitifitas & Spesifisitas & P \\
\hline PCT & 0,93 & $>0,5 \mathrm{ng} / \mathrm{ml}$ & 0,400 & 20 & 30,4 & 0,490 \\
CRP & 8,404 & $>6 \mathrm{mg} / \mathrm{L}$ & 0,422 & 60 & 69,6 & 0,589 \\
Leukosit & 8835 & $>11.000 / \mathrm{iu}$ & 0,500 & 20 & 21,7 & 1,000 \\
\hline
\end{tabular}

Tabel 3. Rerata PELOD dan PRISM

\begin{tabular}{lcccc}
\hline \multirow{2}{*}{ Parameter } & \multicolumn{2}{c}{ UGD $(\mathrm{n}=23)$} & \multicolumn{2}{c}{ Ruangan $(\mathrm{n}=5)$} \\
\cline { 2 - 5 } & Hidup & Meninggal & Hidup & Meninggal \\
\hline PELOD & 6,95 & 22,2 & 9,7 & 0 \\
PRISM & 10,01 & 22 & 7,3 & 0 \\
\hline
\end{tabular}

Tabel 4. Rerata kadar PCT, CRP, dan leukosit dibandingkan kultur darah

\begin{tabular}{lccccc}
\hline & S.betahemolytic & S.epidermidis & Serratia & Steril & Total \\
\hline PCT $(\mathrm{ng} / \mathrm{L})$ & 2 & & & & \\
$<0,5$ & 0 & 1 & 3 & 10 & 16 \\
$0,5-2$ & 1 & 0 & 0 & 4 & 4 \\
$>2-5$ & 1 & 0 & 0 & 4 & 5 \\
$>10$ & & 0 & 0 & 2 & 3 \\
CRP $(\mathrm{mg} / \mathrm{L})$ & 3 & & & & \\
$\quad$ Normal & 0 & 0 & 2 & 18 & 24 \\
Infeksi & & & 0 & 4 & 4 \\
Leukosit $(/ \mu \mathrm{l})$ & 2 & 1 & 2 & 9 & 14 \\
$\quad$ Normal & 2 & 0 & 1 & 11 & 14 \\
Infeksi & & & & \\
\hline
\end{tabular}

Tabel 5. Korelasi Spearman's antara PCT dengan CRP dan leukosit

\begin{tabular}{lccl}
\hline & $\mathrm{p}$ & $\mathrm{r}$ & Keterangan \\
\hline PCT-biakan & 0,452 & 0,15 & Korelasi (-) \\
CRP-biakan & 0,598 & 0,104 & Korelasi (-) \\
Leukosit-biakan & 1.000 & 0,00 & Korelasi (-) \\
PCT-CRP & 0,666 & 0,085 & Korelasi (-) \\
PCT-leukosit & 0,710 & 0,074 & Korelasi (-) \\
CRP-leukosit & 0,551 & 0,118 & Korelasi I (-) \\
\hline
\end{tabular}

dijumpai pada 1 subyek dengan biakan darah positif. Nilai CRP meningkat atau yg menunjukkan adanya infeksi bakterial terjadi pada semua subyek (4 orang) dengan biakan darah steril sedangkan leukositosis (11 subyek penelitian) menunjukkan biakan darah steril dan hanya 3 subyek biakan darah positif.

Tabel 5 memperlihatkan hubungan negatif antara PCT dengan biakan $(r=0,15: p=0,454)$ begitu pula hubungan kadar PCT dengan CRP ( $\mathrm{r}=0,666: \mathrm{p}=0,085)$ dan tidak ditemukan adanya korelasi antara PCT dan leukosit $(r=0,074: p=0,710)$

\section{Pembahasan}

Kelompok usia 5-10 tahun meliputi 65,4\% dari keseluruhan subyek penelitian dan menyusul kelompok usia $>10$ tahun $(31,8 \%)$. Rerata lama perawatan 4,07 hari dan $53,6 \%$ subyek masuk pada demam hari ke- 5 . Semua subyek merupakan infeksi dengue sekunder (100\%). Berdasarkan rujukan 23 subyek $(82,2 \%)$ dikirim melalui UGD dan hanya 5 orang $(17,8 \%)$ dikirim dari ruangan. Kematian terjadi pada 10,7\% subyek yang semuanya berasal dari UGD. Hung $\mathrm{dkk}^{17}$ mendapatkan $80,8 \%$ pasien SSD memiliki status gizi 


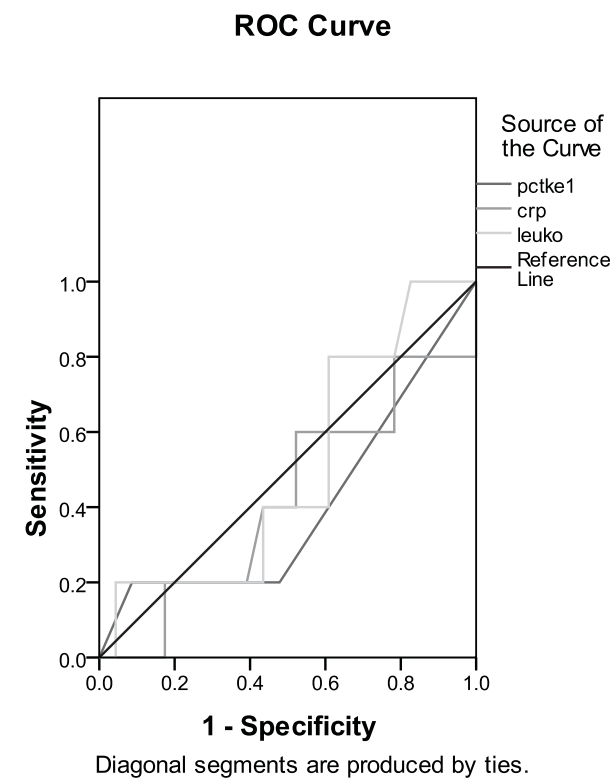

Gambar 1. ROC antara PCT, leukosit, dan CRP

baik. Willis $\mathrm{dkk}^{18}$ mendapatkan sebagian besar subyek penelitian dirawat pada hari demam ke-5 sampai ke-7. Penelitian kami menunjukkan perdarahan terjadi pada $42,9 \%$ pasien DSS dan gejala kejang (ensefalopati) 17,9 subyek, hepatomegali pada $21,4 \%$ pasien dan muntah $71,4 \%$. Lum $\mathrm{dkk}^{19}$ mendapatkan $32 \%$ pasien SSD menunjukkan gejala ensefalopati. Hung $\mathrm{dkk}^{17}$ mendapatkan 7\% pasien DBD dengan atau tanpa syok menunjukkan gejala ensefalopati. Raihan $\mathrm{dkk}^{20}$ mendapatkan $86 \%$ kasus hepatomegali dan $31 \%$ perdarahan saluran cerna pada SSD.

Syok pada DBD dapat menyebabkan iskemia usus dan menyebabkan translokasi bakteri dari lumen usus ke dalam sirkulasi. Endotoksin ini akan mengaktivasi sitokin terutama TNF- $\alpha$ dan IL-1. Penelitian Hadinegoro ${ }^{21}$ membuktikan bahwa endotoksemia berhubungan erat dengan syok pada DBD. Endotoksemia terjadi pada $75 \%$ SSD dan 50\% DBD non syok

Pemeriksaan endotoksin belum tersedia secara komersial di Jakarta. Hurley ${ }^{22}$ melakukan metaanalisis dari 46 studi mengenai endotoksin dengan pemeriksaan Limulus amebocite lysate assay sebagai gold standart, didapatkan hasil endotoksin positif $27 \%$ dari bakteremia dengan Salmonella enterica serovar Typhi, 82\% pada bakteremia Neisseria meningitidis, dan 93\% pada bakteremia Pseudomonas pseudomallei. Bila penyebab bakteremia dibedakan berdasarkan golongan enterobakteriase atau non enterobakteriase maka hasil pemeriksaan endotoksin positif pada bakteremia golongan non enterobakteriase 59\% dan pada golongan enterobakteriase $43 \%$. Pemeriksaan endotoksin lain yaitu dengan metode endotoxin activity assay, didapatkan dari 58\% hasil positif endotoksin $13,5 \%$ terbukti positif terinfeksi bakteri gram negatif. ${ }^{23}$

Biakan darah positif pada penelitian kami hanya pada satu subyek dengan kadar PCT $>10$ dan pada PCT normal $<0,5$ terdapat 6 subyek dengan biakan darah positif, dibandingkan pada kadar CRP meningkat tidak terdapat biakan darah yang positif sedangkan pada leukositosis terdapat 11 subyek penelitian yang menunjukkan biakan darah steril hanya 3 subyek positif dan 3 subyek penelitian yang meninggal ternyata ditemukan semua biakan darah steril.

Secara klinis sangat diperlukan pemeriksaan yang dapat membedakan apakah SIRS (Systemic Inflamatory Response Syndrome) disebabkan oleh infeksi bakteri atau bukan infeksi bakteri. Salah satu pemeriksaan laboratorium yang dapat membedakan keadaan ini adalah pemeriksaan prokalsitonin. ${ }^{3}$ Penelitian yang dilakukan pada penyakit tertentu menunjukkan PCT merupakan marker terbaik pada berbagai subpopulasi pasien ICU untuk membedakan SIRS non-infeksi dan infeksi. ${ }^{24}$

Penelitian awal dampak ekonomis penggunaan PCT secara sistematis untuk mendiagnosis dan monitoring proses peradangan dan infeksi menunjukkan hasil yang baik melalui pengurangan pemakaian antibiotik, waktu yang lebih pendek di ICU, dan menurunkan biaya per pasien. ${ }^{25}$

Pemeriksaan PCT merupakan surrogate marker untuk infeksi, dalam kaadaan normal PCT dimetabolisme menjadi kalsitonin, pada keadaan infeksi atau stress lain perubahan PCT menjadi kalsitonin terganggu sehingga kadar PCT meningkat. ${ }^{26}$ Pada penelitian kami kadar PCT normal terjadi pada hampir sebagian besar subyek penelitian $(57,1 \%)$, peningkatan ringan $14,3 \%$, peningkatan sedang $17,9 \%$ dan hanya 10,7 $\%$ yang menunjukkan infeksi berat. Menurut Leclerc $\mathrm{dkk}^{14}$ kadar PCT pada beberapa keadaan inflamasi didapati normal kadar PCT $<0,5 \mathrm{ng} / \mathrm{ml}$, inflamasi kronik dan penyakit autoimun kadar PCT $<0,5 \mathrm{ng} /$ $\mathrm{ml}$, infeksi virus dan Infeksi lokal kadar PCT $<0,5 \mathrm{ng} /$ $\mathrm{ml}$ sedangkan SIRS, multipel trauma, luka bakar kadar PCT 0,5-2 ng/ml dan infeksi berat, sepsis, kegagalan beberapa organ (multiple organ failure) kadar PCT > 
2 (paling sering 10-100) $\mathrm{ng} / \mathrm{ml}$.

Kadar CRP positif pada $25 \%$ subyek penelitian sedangkan leukositosis terjadi pada 50\% subyek dan, hemokonsentrasi ditemukan pada $46,4 \%$ subyek. Beberapa penelitian mengenai PCT menunjukkan bahwa pemeriksaan PCT berguna sebagai marker diagnosis dan dapat digunakan untuk menilai beratnya infeksi bakterial, tetapi tidak untuk infeksi virus dan infeksi bakteri lokal sehingga dianggap PCT hanya akan meningkat bila terjadi infeksi bakterial sistemik. ${ }^{27}$

Pada penelitian kami menunjukkan rerata kadar PCT $0,93 \mathrm{mg} / \mathrm{L}$, nilai ROC 0,400 mempunyai sensitifitas 20\% dan spesifisitas 30,4\% dengan nilai $\mathrm{p}=0,490$. Rerata kadar CRP 8,4 mg/L, nilai ROC 0,422 mempunyai sensitifitas $60 \%$ dan spesifisitas $69,6 \%$ dengan nilai $\mathrm{p}=0,589$. Sedangkan rerata kadar leukosit $8835 / \mathrm{iu}$ dengan nilai ROC 0,500 mempunyai sensitifitas $20 \%$ dan spesifisitas $21,7 \%$ dengan nilai $\mathrm{p}=1,00$.

Beberapa penelitian menunjukkan pemeriksaan PCT lebih baik dari CRP ${ }^{15,28}$ terutama untuk membedakan beratnya sepsis dan prognosis perjalanan penyakit, sedangkan untuk membedakan sepsis dan non sepsis kemampuannya sama.

Menurut Carrol $\mathrm{dkk}^{15}$ ditemukan perbandingan karakteristik hitung leukosit, CRP dan PCT sebagai petanda infeksi kadar PCT $>2 \mathrm{ng} / \mathrm{ml}$ dengan menunjukkan nilai sensitifitas 94\%, spesifisitas 93\%, PPV 95\%, dan NPV 91\% sedangkan untuk CRP > 30 $\mathrm{mg} / \mathrm{l}$ didapati sensitifitas $81 \%$, spesifisitas $89 \%$, PPV $91 \%$, dan NPV $76 \%$ dan jumlah leukosit $<4000$ atau $>15.000 / \mathrm{mm} 3$ terdapat sensitifitas $69 \%$ spesifisitas 67\% PPV 77\% NPV 56\% dibandingkan pula jika PCT + CRP ditemukan sensitifitas $80 \%$ spesifisitas 95\% PPV 96\% NPV 76\%

Pada neonatus yang mengalami sepsis, pemeriksaan PCT mempunyai sensitifitas $77 \%$ dan spesifisitas $91 \%$ untuk sepsis dini $(0-12 \text { jam })^{29}$ Penelitian sepsis lainnya pada neonatus menunjukan kadar PCT sebagai marker pada sepsis neonatus ${ }^{30,31}$ Penelitian pada pneumonia untuk membedakan penyebabnya virus atau bakterial didapatkan snsitivitas $68,6 \%$ dan spesifisitas $79,4 \%$ untuk PCT juga dapat membedakan penyebab etiologi lainnya didapati sensitifitas $90,3 \%$ dan spesifisitas sebesar $74,1 \% .^{32}$ Penelitian yang mengkaitkan kadar PCT dengan beratnya infeksi dan prognosis, menunjukkan kadar PCT meningkat sesuai beratnya infeksi dan mencapai puncak pada syok septik. ${ }^{33} \mathrm{Carrol}^{15}$ melakukan penelitian PCT dibandingkan dengan CRP dan leukosit pada anak yang menderita meningokokus ternyata pemeriksaan PCT lebih baik dari CRP untuk mendiagnosis sepsis dan menentukan prognosis.

Didapatkan korelasi negatif antara PCT, CRP dan leukosit dibandingkan hasil biakan darah demikian pula korelasi antara PCT dengan CRP dan PCT dengan leukosit maupun CRP dengan leukosit semuanya menunjukkan korelasi negatif. Penelitian yang mengkaitkan antara pemeriksaan CRP dengan beratnya sepsis menunjukkan hasil yang kurang jelas. Beberapa penelitian menunjukkan kadar CRP berhubungan dengan derajat sepsis, ${ }^{34,35}$ sedangkan peneliti lain mengatakan sebaliknya. ${ }^{29}$

Disimpulkan bahwa pemeriksaan PCT, CRP, serta hitung leukosit tidak dapat digunakan untuk memprediksi adanya infeksi bakterial pasien SSD yang dirawat di PICU.

\section{Daftar pustaka}

1. WHO. Situation update of dengue in the SEA region 2010. (Diakses 23 Oktober 2010). Diunduh dari: www. searo.who.int

2. Setiati TE. Pengelolaan syok pada demam berdarah dengue anak. Dalam: Sutaryo, Hagung P, Mulatsih S, penyunting. Tatalaksana syok dan perdarahan pada DBD. Yogyakarta: Medica Medical School of Gajahmada University; 2004.h.75-86.

3. Meisner M. Pathobiochemistry and clinical use of procalcitonin. Clin Chim Acta 2002; 323: 17-29

4. Ittner L, Born W, Rau B, Steinbach G, Fischer JA. Circulating procalcitonin and cleavage products in septicaemia compared with medullary thyroid carcinoma. Eur J Endocrinol 2002; 147: 727-31.

5. Claeys R, Vinken S, Spapen H, ver Elst K, Decochez $\mathrm{K}$, Huygenhens L, dkk. Plasma PCT and CRP in acute septic shock: clinical and biological correlates. Crit Care Med 2002; 30: 757-62.

6. Chiwakata CB, Manegold C, Bonicke L, Julch C, Dietrich M. Procalcitonim as a parameter of disease severity and risk mortality in patients with Plasmodium falciparum malaria. J Infect Dis 2001; 183: 161-4.

7. Christofilopoulou S, Charvalos E, Petrikkos G. Could procalcitonin be a predictive biological marker in systemic fungal infections? Study of 14 cases. Eur J Internal Med 2002; 13: 493-5.

8. Meisner M, Rauschmayer C, Schmidt J, Feyrer R, Cesnjevar R, Bredle D, Tschaikowsky K. Early increase PCT after cardiovascular surgery in patients with post opera- 
Henny Rosita Iskandar dkk: Sensitifitas dan spesifisitas pemeriksaan PCT, CRP, dan hitung leukosit untuk memprediksi infeksi pada pasien PICU dengan SSD

tive complication. Intensive Care Med 2002;28:1094102.

9. Kylanpaa-Back ML, Takala A, Kemppainen EA, Puolakkainen PA, Haapiainen R, Repo H. Procalcitonin strip test in the early detection of severe acute pancreatitis. $\mathrm{Br}$ J Surg 2001;88:1-6.

10. Dehne MG, Sablotzki A, Hoffmann A, Mühling J, Dietrich FE, Hempelmann G. Alterations of acute phase reaction and cytokine production in patients following severe burn injury. Burns 2002; 28:535-42.

11. Okada Y, Minakami H, Tomomasa T, Kato M, Inoue Y, Kozawa K, dkk. Serum procalcitonin concentration in patients with Kawasaki disease. J Infect 2004;48:199205.

12. Geppert A, Steiner A, Delle-Karth G, Heinz G, Huber K. Usefulness of procalcitonin for diagnosing complicating sepsis in patients with cardiogenic shock. Intensive Care Med 2003;29: 1384-9.

13. Morgenthaler N, Struck J, Fischer-Schulz C, SeidelMüller E, Beier W, Bergmann A. Detection of procalcitonin (PCT) in healthy controls and patients with local infection by a sensitive ILMA. Clin Lab 2002;48:263-70.

14. Leclerc F, Leteurtre S, Noizet O, Dorkenoo A, Sadik A, Cremer R, Fourier C. Procalcitonin as a prognostic marker in children with meningococcal septic shock. Arch Dis Child 2002;87:450.

15. Carrol ED, Newland P, Riodan FAI, Thomson APJ, Curtis N, Hart CA. Procalcitonin as a diagnostic marker of meningococcal disease in children presenting with fever and rash. Arch Dis Child 2002;86:282-5.

16. Luzzani A, Polati E, Dorizzi R, Rungatcher A, Pavan $\mathrm{R}$, Merlini A. Comparation of procalcitonin and C-reactive protein as marker of sepsis. Crit Care Med 2003;31:1737-41.

17. Hung NT, Lan NT, Lei H, Lin Y, Lien L, Huang K dkk. Association between sex, nutritional status, severity of dengue hemorrhagic fever, and immune status in infants with dengue hemorrhagic fever. Am J Trop Med Hyg 2005;72:370-4.

18. Willis BA, Oragui EE, Stephen AC, Daramola OA, Dung NM, Loen HT, dkk. Coagulation abnormalities in dengue hemorrhagic fever: serial investigation in 167 Vietnamese children with dengue shock syndrome. Clin Infect Dis 2002;35:277-85.

19. Lum L, Gob A, Chan P, El-Amin A, Lam S. Risk factors for hemorrhage in severe dengue infection. J Pediatr 2002;140:629-31.

20. Raihan, Hadinegoro SRS, Tumbelaka AR. Faktor prognosis terjadinya syok pada demam berdarah dengue. Sari Pediatri 2010;12:47-52.

21. Hadinegoro SRS. Telaah endotoksemia pada perjalanan penyakit demam berdarah dengue: Perhatian khusus pada syok, produksi TNF-, interleukin 6 dan sebagai factor predictor demam berdarah dengue berat (Disertasi). Jakarta: Fakultas kedokteran Universitas Indonesia; 1996.

22. Hurley JC. Diagnosis of endotoxemia with Gramnegative bacteremia is bacterial spesies dependent: a meta-analysis of clinical studies. J Clin Microbiol 2009;47:3826-31.

23. Marshall JC, Walker PM, Foster DM, Harris D, Ribeiro M, Paice J, dkk. Measurement of endotoxin activity in critical ill patients using whole blood neutrophil dependent chemiluminescence. Crit Care 2002;6:34248.

24. Giamarellos-Bouboulis EJ, Grecka P, Poulakou G, Anargyrau K, Katsilambros N, Giamarellou H, dkk. Assessment of procalcitonin as a diagnostic marker of underlying infection in patients with febrile neutropenia. Clin Infect Dis 2001;32:1718-25.

25. Van Rossum AM, Wulkan RW, Oudesluys-Murphy AM. Procalcitonin as an early marker of infection in neonates and children. Lancet Infect Dis 2004;4:20-30.

26. Latief A. Pendekatan diagnosis sepsis. Makalah Lengkap Simposium Pediatri Gawat Darurat VI. FK USU Medan 2004.

27. Arkader R, Troster EJ, Lopes MR, Junior RR, Carcillo J, Leoni C, Okay TS. Procalcitonin does discriminate between sepsis and systemic inflammatory response syndrome. Arch Dis Child 2006;91:117-20.

28. Luzzani A, Polati E, Dorizzi R, Rungatcher A, Pavan $\mathrm{R}$, Merlini A. Comparation of procalcitonin and C-reactive protein as marker of sepsis. Crit Care Med 2003;31:1737-41.

29. Resch B, Gusenleitner W, Müller WD. Procalcitonin and interleukin- 6 in the diagnosis of early-onset sepsis of the neonate. Acta Paediatr 2003;92:243-5.

30. Athhan F, Akagündüz B, Genel F, Bak M, Can D. Procalcitonin: A marker of neonatal sepsis. J Trop Pediatr 2002;48:10-4.

31. Blommendahl J, Janas M, Laine S, miettinen A, Ashorn P. Comparison of procalcitonin with CRP and differential white blood cell count for diagnosis of culture-proven neonatal sepsis. Scand J Infect Dis 2002;34:620-2.

32. Polzin A, Pietz M, Erbes R, Raffenberg M, Mauch H, Wagner S, dkk. Procalcitonin as a diagnostic tool in lower respiratory tract infections and tuberculosis. Eur Resp J

Sari Pediatri, Vol. 12, No. 4, Desember 2010 
Henny Rosita Iskandar dkk: Sensitifitas dan spesifisitas pemeriksaan PCT, CRP, dan hitung leukosit untuk memprediksi infeksi pada pasien PICU dengan SSD

2003;21:939-43.

33. Clec'h C, Ferriere F, Karoubi P, Fosse JP, Cupa M, Hoang P, Cohen Y. Diagnostic and prognostic value of procalcitonin in patients with septic shock. Crit Care Med 2004;32:1166-9.

34. Harbart S, Holeckova K, Froidevoux C, Pittet D, Ricou B, Grau GE, dkk, and Geneva septic Network.
Diagnostic value of procalcitonin, interleukin-6, and interleukin-8 in critical ill patients with suspected sepsis. Am J Respir Crit Care Med 2001;164:397-402.

35. Castelli GP, Pognani C, Meisner M, Stuani A, Bellomi D, Sgarbi L. Procalcitonin and C-reactive protein during systemic inflammatory response syndrome, sepsis and organ dysfunction. Crit Care 2004;8:234-42. 